\title{
Defining the Indications for Prophylactic Percutaneous Endoscopic Gastrostomy Tubes in Surgically Treated Head and Neck Cancer Patients
}

\author{
Jason Foster1, Peter Filocamoํㅐ, William Brady², \\ Thom Loree ${ }^{1}$ and John F. Gibbs ${ }^{1}$ \\ ${ }^{1}$ Department of Surgery, Roswell Park Cancer Institute, \\ State University of New York at Buffalo, Elm \& Carlton Streets, Buffalo, NY \\ ${ }^{2}$ Department of Biostatics, Roswell Park Cancer Institute, \\ State University of New York at Buffalo, Elm \& Carlton Streets, Buffalo, NY
}

U.S.A.

\section{Introduction}

Malnutrition is a common problem in head and neck cancer with up to $50 \%$ of the patients developing some degree of nutritional deficiency. ${ }^{1}$ The etiologies of this problem can be divided into two categories: tumor related or treatment related. Patient with tumor related malnutrition typically present with obvious clinical signs and symptoms of undernourishment. Tumor cachexia can contribute but this is primarily caused by physical impediments to oral consumption such as pain, oropharygeal obstruction, or nerve compression, all resulting in discordant degluttination. ${ }^{2}$ Prior to definitive cancer therapy, this group of patients requires nutritional resuscitation.

Additionally many patients who present nutritionally sound and who undergo surgical resection experience some degree of postoperative nutritional difficulties. In many cases it a short lived and inconsequential. However, a subset of patients will experience a more severe prolonged course requiring enteral supplementation. Prior studies have shown that if these patients are not supplemented, they will likely experience severe dehydration, treatment intolerance, or severe treatment related complications that require hospitalization.3,4 Inherently, the surgical treatment of head and neck malignancies can be quite debilitating and result in significant mastication and deglutination dysfunction. ${ }^{5-7}$ At times this involves radical resections that require complex reconstructions to maintain oropharyngeal continuity; and adjuvant radiation and/or chemotherapy may be required to maximize local control. Indiscriminately placing PEG tubes in all patients would put many patients at risk for PEG related complications. ${ }^{8-13}$ Therefore, the difficulty has been trying to preoperatively identify which patients likely to experience prolonged treatment induced malnutrition and benefit from early nutritional supplementation.

Groups have identified some factors that are predictive of a need for enteral support.3,4,14-17 One factor that has been clearly established is radiation therapy, particular when given 
postoperatively.3,4,17 Other factors such as Stage IV disease, base of tongue tumor location, and heavy alcohol ingestion are less clearly defined.14-16 Some criticisms have been that the studies conducted to identify these variables were small, used a mixed population of surgical and non-surgical patients, and often used durations of enteral support that were short $(<4$ weeks) or undefined.

At Roswell Park Cancer Institute (RPCI) prophylactic PEG are routinely placed in surgically treated patients who require a composite resection, flap reconstruction, radiation therapy, chemotherapy, and at the discretion of the attending surgical staff. We found that many patients required their PEG tube for 4 weeks or less; while some patients required their PEG for a year or longer. In order to more accurately define which patients benefited from prophylactic PEG placement we reviewed our experience. We used a homogenous population of surgically treated head and neck cancer patients to identified patient, tumor, and treatment factors that were predictive of a short-term ( $\leq 3$ months) and long-term $(\geq 1$ year) PEG tube dependency.

\section{Methods}

One hundred forty one cases of surgically treated head and neck cancers treated at RPCI from January 1, 1999 to December 31, 2003 who underwent pretreatment placement of PEG tubes were reviewed. Only patients with squamous cell carcinoma (SCC) of the oral cavity, oropharynx, larynx, and pharynx were included in this study eliminating 14 patients. Seven patients had PEG tube placed a second time for the treatment of a new primary or recurrent disease, and six patients did not have complete records, leaving 114 patients for evaluation.

The variables analyzed were divided into patient factors (age and sex), tumor factors (primary site, $\mathrm{T}$ stage and nodal status), and treatment factors (flap reconstruction, radiation, and chemotherapy). A short-term dependency required that the PEG tube be in place for 3 months or less, while a long-term dependency require usage for a year or longer.

\subsection{Statistical method}

The duration of PEG tube dependency was calculated from the date of placement until the time of removal. Patients who had their PEG tube removed and not replaced were considered to be no longer dependent on it. Patients who died while still dependent on their PEG tube, or who were still dependent at last documented follow-up were considered to have censored durations. Because of this censoring, time to event analyses was used. The distribution of PEG duration was compared across age, sex, tumor sites, T stage, $\mathrm{N}$ stage, flap reconstruction, radiation, and chemotherapy. Kaplan-Meier estimates of the proportions (and 95\% confidence intervals \{CIs\}) of patients with PEG tubes in place at 3 and 12 months after placement were determined for each variable and log-rank tests were used to compare durations.

Proportional hazards regression models were used to compare durations while accounting for other factors. Variables were selected for inclusion in the model in a stepwise selection process. Variables were entered in the model if $p<0.05$ and were retained if $p<0.05$. Because a number of patients had unknown T stage (8 patients) and unknown $\mathrm{N}$ stage (20 patients), in the proportional hazards regression models, these factors included separate levels for 
'unknown' $\mathrm{T}$ and 'unknown' $\mathrm{N}$ stage, respectively. In the log-rank analyses of $\mathrm{T}$ stages and $\mathrm{N}$ stages, patients with unknown stages were not included.

These analyses are post hoc so no adjustments for multiplicity are made. All tests were done two-sided with a significance level of 0.05. All analyses were done using SAS version 8.2.

\section{Results}

The mean age of patients in this study was 65 and $65 \%$ of patients were male. Sixty-four percent of the patients had advanced $\mathrm{T}$ stage or recurrent disease and node positive disease was present in $49 \%$ of the patients. Flap reconstructions were performed in $39 \%$ of patients, while the rate of adjuvant therapy was $40 \%$ for radiation and $11 \%$ for chemotherapy. The percentage of patients in each of the four major tumor sites were $42 \%$ oral cavity, $23 \%$ oropharynx, 26\% larynx, and 9\% pharynx. In Table 1 the patient characteristics (age, sex), tumor characteristics ( $\mathrm{T}$ stage, $\mathrm{N}$ stage), and treatment (flap reconstruction, radiation, chemotherapy) characteristic, along with PEG status at the end of the study is presented for each major tumor site. Overall $64 \%(73 / 114)$ of patients in the study had their PEG tubes removed.

Sixty-nine percent of patients had short-term PEG usage. When the group receiving adjuvant radiation was compared to the group that did not receive radiation treatment a significant difference was observed $91 \%(83,99)$ vs. 53\% $(41,65)$. Eighty-nine percent of pharyngeal tumor site patient and $92 \%$ of chemotherapy patients had a short term dependency but this was not statistically different from the other tumors site or the no chemotherapy group respectively. The short-term dependency was not influenced by patient age, sex, $\mathrm{T}$ stage, $\mathrm{N}$ stage, or flap reconstruction (Table 2).

The long-term dependency for this group of patients was $36 \%$. Table 2 presents KaplanMeier estimates of the proportions of patients with PEG tubes in place at 12 months for each variable. PEG tube duration was statistically significantly different across surgical sites: 78\% of pharynx patients still had their tubes in place after 12 months, while only $45 \%$ of oral cavity patients, $34 \%$ of oropharynx patients, and $11 \%$ or larynx patients had tubes in place. Patients who underwent flap reconstruction also had statistically significantly $(p=0.004)$ longer PEG tube durations than those who did not, $52 \%$ vs. $25 \%$, respectively. When a multivariate analysis was performed, adjusting for other factors, site and flap reconstruction remained as statistically significantly long-term risk factors. Chemotherapy was also found to be significant factor in long-term PEG dependency.

\section{Discussion}

The prevention of malnutrition and early nutritional support in the management of cancer patients is well documented. Specifically in head and neck cancer, suboptimal nutrition during definitive treatment results in a significant increase in surgical complications, dehydration, therapy breaks and hospitalizations. (3). Because malnutrition can result in reduced immunosurvelliance, it may contribute to early local and distant cancer recurrence. $(18,19)$ Avoidance of treatment induced malnutrition may prevent these complications, and prophylactic placement of PEG tube provides access for the delivery of nutrition. Identification of the risk factors which contribute to prolonged enteral support ensures PEG placement in the appropriate patients. Of equal importance is that accurate risk 
factors can avoids subjecting low risk patients to PEG related complications, and costs. In this study we found that radiation was the only predictor of a short-term dependency; while pharyngeal tumor site, flap reconstruction, and chemotherapy were predictive a long-term need.

\begin{tabular}{|c|c|c|c|c|c|c|c|c|c|c|}
\hline \multicolumn{9}{|c|}{ Site } & \multirow[b]{3}{*}{$\mathrm{n}$} & \multirow[b]{3}{*}{$\%$} \\
\hline & \multicolumn{2}{|c|}{ Oral cavity } & \multicolumn{2}{|c|}{ Oropharynx } & \multicolumn{2}{|c|}{ Larynx } & \multicolumn{2}{|c|}{ Pharynx } & & \\
\hline & $\mathrm{n}$ & $\%$ & $\mathrm{n}$ & $\%$ & $\mathrm{n}$ & $\%$ & $\mathrm{n}$ & $\%$ & & \\
\hline All & 49 & & 26 & & 30 & & 9 & & 114 & \\
\hline \multicolumn{11}{|l|}{ Removal Category } \\
\hline Died & 10 & 20 & 5 & 19 & 2 & 7 & 6 & 67 & 23 & 20 \\
\hline In Use at End of Follow-up & 11 & 22 & 4 & 15 & 1 & 3 & 1 & 11 & 17 & 15 \\
\hline Removed & 28 & 57 & 17 & 65 & 26 & 87 & 2 & 22 & 73 & 64 \\
\hline Unknown/Loss to Follow-up & 0 & 0 & 0 & 0 & 1 & 3 & 0 & 0 & 1 & 1 \\
\hline \multicolumn{11}{|l|}{ Age, PEG Placed (y) } \\
\hline$<55$ & 10 & 20 & 9 & 35 & 7 & 23 & 2 & 22 & 28 & 25 \\
\hline $55-64$ & 10 & 20 & 8 & 31 & 12 & 40 & 3 & 33 & 33 & 29 \\
\hline $65-74$ & 16 & 33 & 6 & 23 & 7 & 23 & 3 & 33 & 32 & 28 \\
\hline$>=75$ & 13 & 27 & 3 & 12 & 4 & 13 & 1 & 11 & 21 & 18 \\
\hline \multicolumn{11}{|l|}{ Sex } \\
\hline $\mathrm{F}$ & 24 & 49 & 5 & 19 & 8 & 27 & 3 & 33 & 40 & 35 \\
\hline $\mathrm{M}$ & 25 & 51 & 21 & 81 & 22 & 73 & 6 & 67 & 74 & 65 \\
\hline \multicolumn{11}{|l|}{ Chemotherapy } \\
\hline Unknown & 1 & 2 & 0 & 0 & 0 & 0 & 0 & 0 & 1 & 1 \\
\hline No & 46 & 94 & 22 & 85 & 24 & 80 & 9 & 100 & 101 & 89 \\
\hline Yes & 2 & 4 & 4 & 15 & 6 & 20 & 0 & 0 & 12 & 11 \\
\hline \multicolumn{11}{|l|}{ Radiation } \\
\hline Unknown & 1 & 2 & 0 & 0 & 0 & 0 & 0 & 0 & 1 & 1 \\
\hline No & 32 & 65 & 11 & 42 & 19 & 63 & 5 & 56 & 67 & 59 \\
\hline Yes & 16 & 33 & 15 & 58 & 11 & 37 & 4 & 44 & 46 & 40 \\
\hline \multicolumn{11}{|l|}{ Flap Reconstruction } \\
\hline No & 34 & 69 & 7 & 27 & 25 & 83 & 3 & 33 & 69 & 61 \\
\hline Yes & 15 & 31 & 19 & 73 & 5 & 17 & 6 & 67 & 45 & 39 \\
\hline \multicolumn{11}{|l|}{ T Stage } \\
\hline Unknown & 3 & 6 & 3 & 12 & 2 & 7 & 0 & 0 & 8 & 7 \\
\hline Recurrence & 14 & 29 & 7 & 27 & 9 & 30 & 0 & 0 & 30 & 26 \\
\hline $\mathrm{T} 1$ & 2 & 4 & 1 & 4 & 2 & 0 & 2 & 22 & 5 & 4 \\
\hline $\mathrm{T} 2$ & 16 & 33 & 6 & 23 & 5 & 17 & 1 & 11 & 28 & 25 \\
\hline T3 & 5 & 10 & 7 & 27 & 11 & 37 & 4 & 44 & 27 & 24 \\
\hline $\mathrm{T} 4$ & 9 & 18 & 2 & 8 & 3 & 10 & 2 & 22 & 16 & 14 \\
\hline \multicolumn{11}{|l|}{ Node Involvement } \\
\hline Unknown & 6 & 12 & 6 & 23 & 6 & 20 & 0 & 0 & 18 & 16 \\
\hline No & 21 & 43 & 2 & 8 & 13 & 43 & 4 & 44 & 40 & 35 \\
\hline Yes & 22 & 45 & 18 & 59 & 11 & 37 & 5 & 56 & 56 & 49 \\
\hline
\end{tabular}

Table 1. Characteristics of Patients by Surgical Site 


\begin{tabular}{|c|c|c|c|c|c|c|}
\hline & \multirow{2}{*}{$\begin{array}{l}\mathbf{N} \\
\mathbf{T}\end{array}$} & \multirow{2}{*}{$\begin{array}{l}\text { Median } \\
\text { Duration } \\
(95 \% \mathrm{CI})\end{array}$} & \multicolumn{2}{|c|}{$\begin{array}{l}\text { Percent }(95 \% \text { CI }) \text { of Patients With } \\
\text { PEG at }\end{array}$} & \multirow{2}{*}{$\begin{array}{l}\text { p (log- } \\
\text { rank) }\end{array}$} & \multirow{2}{*}{$\begin{array}{l}\text { p for } \\
\text { selected } \\
\text { covariates } \\
\ddagger \\
\end{array}$} \\
\hline & & & 3 months & 12 months & & \\
\hline \multicolumn{7}{|l|}{ Site } \\
\hline Oral cavity & 49 & $11.2(4.1, \mathrm{NE})$ & $64 \%(51 \%, 78 \%)$ & $45 \%(31 \%, 60 \%)$ & \multirow{4}{*}{-0.007} & \multirow{4}{*}{0.004} \\
\hline Oropharynx & 26 & $6.6(4.0,18.2)$ & $80 \%(64 \%, 96 \%)$ & $34 \%(15 \%, 53 \%)$ & & \\
\hline Larynx & 30 & $3.5(2.6,5.9)$ & $62 \%(45 \%, 80 \%)$ & $11 \%(0 \%, 23 \%)$ & & \\
\hline Pharynx & 9 & $\mathrm{NE}$ & $89 \%(68 \%, 100 \%)$ & $78 \%(51 \%, 100 \%)$ & & \\
\hline \multicolumn{7}{|c|}{ Age, PEG Placed (y) } \\
\hline$<55$ & 28 & $7.1(4.7,11.3)$ & $78 \%(63 \%, 94 \%)$ & $29 \%(11 \%, 47 \%)$ & \multirow{4}{*}{-0.157} & \multirow{4}{*}{ NA } \\
\hline $55-64$ & 33 & $3.1(2.3,6.6)$ & $52 \%(34 \%, 69 \%)$ & $26 \%(10 \%, 41 \%)$ & & \\
\hline $65-74$ & 32 & $11.2(5.0, \mathrm{NE})$ & $87 \%(75 \%, 99 \%)$ & $50 \%(31 \%, 68 \%)$ & & \\
\hline$\geq 75$ & 21 & $4.4(2.6,19.1)$ & $60 \%(38 \%, 81 \%)$ & $41 \%(18 \%, 64 \%)$ & & \\
\hline \multicolumn{7}{|l|}{ Sex } \\
\hline $\mathrm{F}$ & 40 & $5.0(4.0,11.2)$ & $68 \%(54 \%, 83 \%)$ & $32 \%(16 \%, 48 \%)$ & \multirow{2}{*}{0.583} & \multirow{2}{*}{ NA } \\
\hline $\mathrm{M}$ & 74 & $6.6(4.9,11.3)$ & $70 \%(59 \%, 80 \%)$ & $37 \%(25 \%, 49 \%)$ & & \\
\hline \multicolumn{7}{|l|}{ Radiation } \\
\hline No & 67 & $3.2(2.3,8.7)$ & $53 \%(41 \%, 65 \%)$ & $34 \%(22 \%, 46 \%)$ & \multirow{2}{*}{-0.102} & \multirow{2}{*}{ NA } \\
\hline Yes & 46 & $8.2(6.6,13.8)$ & $91 \%(83 \%, 99 \%)$ & $38 \%(23 \%, 53 \%)$ & & \\
\hline \multicolumn{7}{|c|}{ Chemotherapy } \\
\hline No & $\begin{array}{l}10 \\
1\end{array}$ & $5.9(4.1,8.7)$ & $66 \%(57 \%, 76 \%)$ & $35 \%(25 \%, 44 \%)$ & \multirow[t]{2}{*}{0.141} & \multirow[t]{2}{*}{$<0.001$} \\
\hline Yes & 12 & $10.6(4.9, \mathrm{NE})$ & $92 \%(76 \%, 100 \%)$ & $46 \%(17 \%, 76 \%)$ & & \\
\hline \multicolumn{7}{|c|}{ Flap Reconstruction } \\
\hline No & 69 & $4.9(2.7,6.6)$ & $62 \%(50 \%, 73 \%)$ & $24 \%(13 \%, 35 \%)$ & \multirow{2}{*}{0.002} & \multirow{2}{*}{0.011} \\
\hline Yes & 45 & $18.2(5.6, \mathrm{NE})$ & $82 \%(70 \%, 93 \%)$ & $54 \%(38 \%, 69 \%)$ & & \\
\hline \multicolumn{7}{|l|}{ T Stage } \\
\hline Recurrence & 30 & $5.9(2.7,18.2)$ & $66 \%(49 \%, 83 \%)$ & $42 \%(22 \%, 61 \%)$ & \multirow{5}{*}{0.151} & \multirow{5}{*}{ NA } \\
\hline $\mathrm{T} 1$ & 5 & $\mathrm{NE}$ & $80 \%(45 \%, 100 \%)$ & $53 \%(5 \%, 100 \%)$ & & \\
\hline $\mathrm{T} 2$ & 28 & $6.3(3.8,11.3)$ & $71 \%(55 \%, 88 \%)$ & $27 \%(9 \%, 45 \%)$ & & \\
\hline T3 & 27 & $5.0(2.6,9.9)$ & $66 \%(48 \%, 84 \%)$ & $24 \%(7 \%, 41 \%)$ & & \\
\hline $\mathrm{T} 4$ & 16 & $\mathrm{NE}$ & $80 \%(60 \%, 100 \%)$ & $60 \%(35 \%, 85 \%)$ & & \\
\hline \multicolumn{7}{|c|}{ Node Involvement } \\
\hline No & 40 & $5.4(2.6,8.7)$ & $62 \%(47 \%, 77 \%)$ & $33 \%(18 \%, 49 \%)$ & \multirow{2}{*}{-0.663} & \multirow{2}{*}{ NA } \\
\hline Yes & 56 & $6.6(4.7,11.2)$ & $74 \%(63 \%, 86 \%)$ & $30 \%(18 \%, 43 \%)$ & & \\
\hline $\begin{array}{l}\text { I At PEG place } \\
\dagger \text { Percents and } \\
\text { † From likeliho } \\
\text { stepwise select } \\
\mathrm{NA}=\text { not appli } \\
\mathrm{NE}=\text { not estim }\end{array}$ & & $\begin{array}{l}\text { are Kaplan-Mei } \\
\text { tests for selectec } \\
\text { rm not selected } \mathrm{f}\end{array}$ & $\begin{array}{l}\text { ier estimates. } \\
\text { d covariates from pro } \\
\text { for inclusion in prop }\end{array}$ & $\begin{array}{l}\text { pportional hazards re } \\
\text { ortional hazards regre }\end{array}$ & $\begin{array}{l}\text { ressi } \\
\text { sion }\end{array}$ & $\begin{array}{l}\text { nodels using } \\
\text { del). }\end{array}$ \\
\hline
\end{tabular}

Table 2. Time-to-Event Analyses of PEG Duration 
Other groups have documented that radiation treatment results in significant malnutrition.(3,4,20) Radiation treatment often results in xerostomia, loss of taste, mucositis, and tumor edema which all contribute to poor oral intake and nutritional deficits. When patients receive primary radiation without nutritional support $40 \%$ of patient loose more than $10 \%$ of their baseline weights, $40 \%$ of patients require hospitalization during the treatment with $20 \%$ of patients requiring therapy break, and $40 \%$ of these patients will require a gastrostomy placement to complete therapy. $(3,4,20)$ As expected $91 \%$ of patients who received radiation in addition to surgical resection required short term enteral support. However, this dependency was self-limited, and did not impact long term oral nutrition, evident by no difference at 1 year between the radiated or unirradiated (Table 2).

A pharyngeal site was significant on univariate analysis, while flap reconstruction was significant on both univariate and multivariate analysis. Given the significant amount of dysfunction associated with these surgical procedures, this data validates our clinical expectation that these subsets benefit from prophylactic PEGs. Importantly, given the propensity of oral pharyngeal bacterial overgrowth in this patient subset and significant intra-oral tumor burden, we believe that the T-fastener technique should be used to prevent/reduce PEG site abscess and local cancer recurrence. We previously published that the T-fastener technique has a low rate of local infection and cancer recurrence in head and neck carcinoma population. (21)

Chemotherapy was the only other significant factor on multivariate analysis. Although our series was small, the increasing use of chemotherapy in the management of the head and neck SCC population will dramatically increase this patient fraction requiring nutritional support. In our study almost half of chemotherapy patients required long-term support. We believe that prophylactic PEG placement should be part of the management discussion in patients receiving adjuvant or neoadjuvant chemotherapy.

Importantly when PEG tubes are placed in this patient population, the usage of the Tfastener technique is critical. Most of these patients are at high risk for PEG site infection and tumor implantation when the pull through technique is used in this patient population. We recently published that the rate of these complications can be significantly reduced by direct PEG placement with T-fastener strategy.

This review confirmed the favorable current approach to prophylactic PEG tube in the head and neck cancer population. Aside from patients who present malnourished, prophylactic PEG tubes should be placed in all SCC head and neck cancer patients who have a pharyngeal primary tumor site, require flap reconstruction, undergo radiation therapy, and/or chemotherapy.

\section{References}

[1] Bassett MR, Dobie RA: Patterns of nutritional deficiency in head and neck cancer. Otolaryngol Head Neck Surg 91:119-25, 1983

[2] Logemann JA, Bytell DE: Swallowing disorders in three types of head and neck surgical patients. Cancer 44:1095-105, 1979

[3] Fietkau R, Iro H, Sailer D, et al: Percutaneous endoscopically guided gastrostomy in patients with head and neck cancer. Recent Results Cancer Res 121:269-82, 1991 
[4] Lee JH, Machtay M, Unger LD, et al: Prophylactic gastrostomy tubes in patients undergoing intensive irradiation for cancer of the head and neck. Arch Otolaryngol Head Neck Surg 124:871-5, 1998

[5] Martini DV, Har-El G, Lucente FE, et al: Swallowing and pharyngeal function in postoperative pharyngeal cancer patients. Ear Nose Throat J 76:450-3, 456, 1997

[6] Vokes EE, Kies MS, Haraf DJ, et al: Concomitant chemoradiotherapy as primary therapy for locoregionally advanced head and neck cancer. J Clin Oncol 18:1652-61, 2000

[7] Murry T, Madasu R, Martin A, et al: Acute and chronic changes in swallowing and quality of life following intraarterial chemoradiation for organ preservation in patients with advanced head and neck cancer. Head Neck 20:31-7, 1998

[8] Baredes S, Behin D, Deitch E: Percutaneous endoscopic gastrostomy tube feeding in patients with head and neck cancer. Ear Nose Throat J 83:417-9, 2004

[9] Ehrsson YT, Langius-Eklof A, Bark T, et al: Percutaneous endoscopic gastrostomy (PEG) - a long-term follow-up study in head and neck cancer patients. Clin Otolaryngol Allied Sci 29:740-6, 2004

[10] Hunter JG: Tumor implantation at PEG exit sites in head and neck cancer patients: how much evidence is enough? J Clin Gastroenterol 37:280, 2003

[11] Sharma P, Berry SM, Wilson K, et al: Metastatic implantation of an oral squamous-cell carcinoma at a percutaneous endoscopic gastrostomy site. Surg Endosc 8:1232-5, 1994

[12] van Erpecum KJ, Akkersdijk WL, Warlam-Rodenhuis CC, et al: Metastasis of hypopharyngeal carcinoma into the gastrostomy tract after placement of a percutaneous endoscopic gastrostomy catheter. Endoscopy 27:124-7, 1995

[13] Tucker AT, Gourin CG, Ghegan MD, et al: 'Push' versus 'pull' percutaneous endoscopic gastrostomy tube placement in patients with advanced head and neck cancer. Laryngoscope 113:1898-902, 2003

[14] Gardine RL, Kokal WA, Beatty JD, et al: Predicting the need for prolonged enteral supplementation in the patient with head and neck cancer. Am J Surg 156:63-5, 1988

[15] Anwander T, Berge S, Appel T, et al: Percutaneous endoscopic gastrostomy for longterm feeding of patients with oropharyngeal tumors. Nutr Cancer 50:40-5, 2004

[16] Schweinfurth JM, Boger GN, Feustel PJ: Preoperative risk assessment for gastrostomy tube placement in head and neck cancer patients. Head Neck 23:376-82, 2001

[17] Scolapio JS, Spangler PR, Romano MM, et al: Prophylactic placement of gastrostomy feeding tubes before radiotherapy in patients with head and neck cancer: is it worthwhile? J Clin Gastroenterol 33:215-7, 2001

[18] van Bokhoust-de van der Schuer, von Blomberg-van der Flier BM, Kuik DJ, Klop, Scholten PE, Siroen MP, Snow GB, Quak, JJ, van Leeuwen PA . Survival of malnourished head and neck cancer patients can be predicted by human leukocyte antigen-DR expression and interleukin-6/tumor necreosis factor-alpha response of the monocyte. J Parenter Enteral Nutr. 24(6):, 329-36, 2000

[19] van Bokhoust-de van der Schuer, van Leeuwen PA, Kuik DJ, Klop WM, Sauerwein HP, Snow GB, Quak, JJ. The impact of nutritional status on the prognoses of patients with advanced head and neck cancer. Cancer 86(3): 519-27, 1999 
[20] Jensen K, Lambertsen K, Grau C. Late swallowing dysfunction and dysphagia after radiotherapy for pharynx cancer: frequency, intensity and correlation with dose and volume parameters. Radiother Oncol 85(1): 74-82, 2007.

[21] Foster J, Filacoma P, Brady W, Nava H, Hicks W, Loree T, Rigual N, Smith J, Gibbs JF. The introducer technique is a safe method for placing percutaneous endoscopic gastrostomy tubes in head and neck cancer patients. Surg Endos 21: 897-01, 2006 


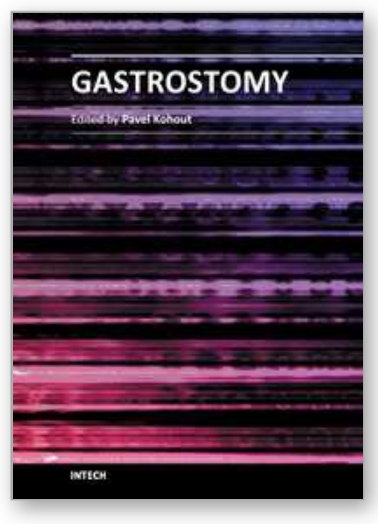

\author{
Gastrostomy \\ Edited by Dr. Pavel Kohout
}

ISBN 978-953-307-365-1

Hard cover, 152 pages

Publisher InTech

Published online 02, December, 2011

Published in print edition December, 2011

The gastrostomy placement is a method of providing nutrition to the patients who are unable to eat. In this book you can find chapters focused on the use of gastrostomy in children, patients with neurological impairment and patients with head and neck tumours. Home enteral nutrition is suitable for all of these groups of patients and is far easier with gastrostomy. The new indications (especially in very young children) required new techniques such as: laparoscopic gastrostomy, laparoscopy assisted endoscopic gastrostomy with/without fundoplication, ultrasonography assisted gastronomy. All information about these techniques can be found in this book. This book does not serve as a basic textbook, but as an interesting reading material and as an aid for physicians who are already familiar with the indication for gastrostomy and want to know more.

\title{
How to reference
}

In order to correctly reference this scholarly work, feel free to copy and paste the following:

Jason Foster, Peter Filocamo, William Brady, Thom Loree and John F. Gibbs (2011). Defining the Indications for Prophylactic Percutaneous Endoscopic Gastrostomy Tubes in Surgically Treated Head and Neck Cancer Patients, Gastrostomy, Dr. Pavel Kohout (Ed.), ISBN: 978-953-307-365-1, InTech, Available from: http://www.intechopen.com/books/gastrostomy/defining-the-indications-for-prophylactic-percutaneousendoscopic-gastrostomy-tubes-in-surgically-tr

\section{INTECH}

open science | open minds

\author{
InTech Europe \\ University Campus STeP Ri \\ Slavka Krautzeka 83/A \\ 51000 Rijeka, Croatia \\ Phone: +385 (51) 770447 \\ Fax: +385 (51) 686166 \\ www.intechopen.com
}

\author{
InTech China \\ Unit 405, Office Block, Hotel Equatorial Shanghai \\ No.65, Yan An Road (West), Shanghai, 200040, China \\ 中国上海市延安西路65号上海国际贵都大饭店办公楼 405 单元 \\ Phone: +86-21-62489820 \\ Fax: $+86-21-62489821$
}


(C) 2011 The Author(s). Licensee IntechOpen. This is an open access article distributed under the terms of the Creative Commons Attribution 3.0 License, which permits unrestricted use, distribution, and reproduction in any medium, provided the original work is properly cited. 